\title{
ANNALS
}

OF THE

\section{Association of American Geographers}

VOLUME 65,1975

JOHN FRASER HART

Editor

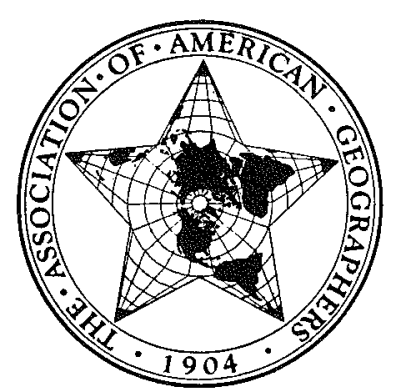

PUBLISHED BY THE ASSOCIATION March, June, September, and December 


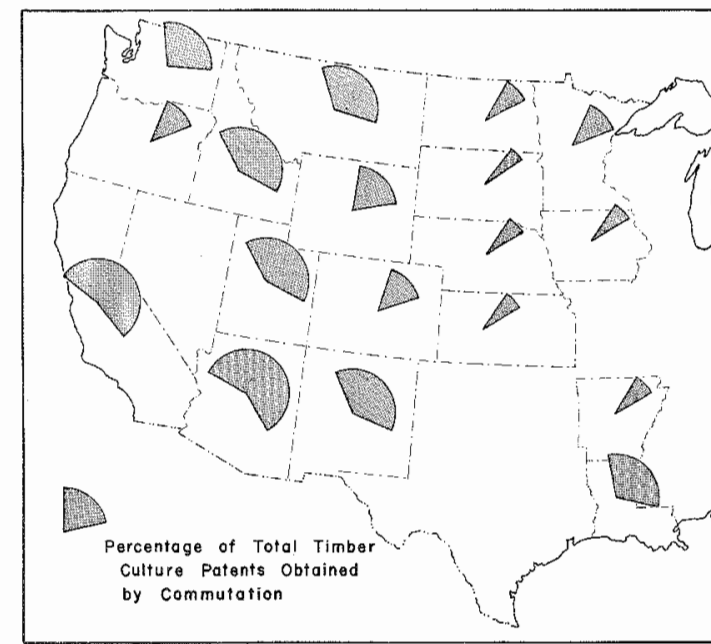

Fig. 7. Percentage of total timber culture patent obtained by commutation. Source: General Lan
Office Report, 1921, p. 65 .

Congress further relaxed the requirements in 1893 by adding the following provision to the 1891 commutation amendment: 43

That if trees, seeds, or cuttings were in good faith planted as provided by law and the same and the land upon which so planted were thereafter in good faith cultivated as provided by law for at least eigh years by a person qualified to make entry and who final proof may be made without regard to the number of trees that may have the land.

After 1893 tree claims could be patented with no payment and with no trees alive on the land

These legislative adjustments made possible the patenting of many timber culture entries which might otherwise have been canceled, and patenting success was increased, but the relaxation of tree growth requirements permitted patenting without achieving the intended tree production, and a large number of treeless tree claims resulted. The repeal of the timber culture laws, a surprise only in that repeal had not

Colorado, to forty-one percent in Idaho, and to fiftyfour and fifty-nine percent, respectively, in Californi and Arizona. Nevada, with only one timber culture patent, cannot be used for statistical comparison of
commuted entries.
43 United States Statutes at Large, 52nd Congress, Sess. II, Ch. 208 (Washington: Government Printin Office, 1893), p. 593. come earlier, was an admission that the stated goals of the original Timber Culture Act had not been accomplished.

\section{SUMMARY}

Land entries and land patents were mapped to provide a geographic base for analyses and explanations of environmental relationships and processes associated with the use of the timber culture entry. Entries in selected townships in the grasslands area overlapping the 1872 settlement frontier zone strongly suggest that the Timber Culture Act must have been intended primarily for the grasslands west of the humid prairies. The major portion of the humid prairies had already been entered before 1872 , when the timber culture bill was introduced in Congress.

The location and the failure to patent a vast majority of timber culture entries filed in an area used primarily for cattle ranching tends to verify early Land Office Reports that the tree claim location was selected by the rancher but filed under the name of his employees, drifters, or relatives to hold the land necessary or grazing his cattle.

Entries mapped in successive years as settlers moved into a new area on the High Plains of Western Nebraska present a sequence in which timber culture entries dominated the initial wave of land filings followed by a wave of homestead filings. The low percentage of patents resulting from original timber culture entries, the high percentage of repeated cancellations and reentries, and the order of entry were all indicators of speculator activity in timber culture filings.

Total entries and patents both dropped sharply within the area of environmental change from the subhumid Great Plains to the arid Southwest. The commutation of timber culture entries, written into the repeal law of 1891, increased from the Great Plains westward and southwestward into the drier areas.

Despite the honorable intentions of the Timber Culture Act, it appears that a majority of the entryman's adaptations and adjustments to the law were primarily speculative land manipulations, excused locally by those participating in such activities as the only way to cope in profitable manner with this inadequate legislation.

\section{PRE-SPANISH PUEBLOS IN NEW MEXICO*}

DIETRICH FLIEDNER

ABSTRACT. Pre-Spanish (1300-1600) pueblos in the Jemez Mountains of New Mexico were compact multistoried buildings which enclosed small plazas. Most of their several hundred rooms were probably occupied by single families, but some were storerooms. Most of the cultivated land was on the flatter areas, but slopes up to $40^{\circ}$ were terraced. The agricultural area probably was cultivated in common, and private ownership of fields was unknown. Each cultivated area had one or several fieldhouses or small caves, mostly of only one room, in which a single family lived and watched the crops during the growing season. Smaller structures, which might be interpreted as observation cabins occupied by only one person, commanded views of larger areas. All structures were connected by foot trails. Perhaps five to seven hundred people lived in a pueblo with 250 to 300 rooms and a cultivated area of 500 to 625 acres (200 to $250 \mathrm{ha}$ ). The community had a tight social structure based on religious societies and elected chiefs rather than on a nobility as in Mexico. KeY words: Field patterns, New Mexico, Population density, Pueblo, Social organization, Trails.

COMPACT one or multistoried village structures remain a characteristic feature of the Indian cultural area in New Mexico and Arizona, although most of these forms are slowly disintegrating under European influence the upper stories are dilapidating, some apartments are abandoned, and gaps are appearing. Some pueblos are almost empty, and new villages of one family houses have been built near by. The economy has also changed. In the last century little fieldhouses, called ranchitos,

Accepted for publication 20 May 1974

Dr. Fliedner is Professor of Geography at the Universität des Saarlandes, 66 Saarbrücken, Federal Republic of Germany.

* An expanded version of this paper will be published in German in the Arbeiten aus dem Geograph schen Institut der Universität des Saarlandes. This research was made possible by the generous support of the American Council of Learned Societies, and by the assistance of the Deutsche Forschungsgemeinschaft. Special support was made by the University of New Mexico in Albuquerque and the Laboratory of Anthropology in Sante $\mathrm{Fe}$. I appreciate the help of Mrs. Ellis, Mrs. Adams, Mrs. H. Warren, Mr. St Peckham, and Dr. Ewing, and I particularly enjoyed the hospitaty and help of colleagues in the DepartMurphy and Snead I appreciate the help of the Editor of the Annals in smoothing out the Englith

ANNALS OF THE ASSOCIATION OF AMERICAN GEOGRAPHERS Vol. 65, No. 3, September 197 were scattered over the area on the tops of hills or in similar exposed places. In the warmer season families lived in these houses to watch the surrounding fields. Today some of these buildings are used as sheds, but most are only ruins. ${ }^{1}$ The fields are divided in small blocks of 0.5 to 1.2 acres $(0.2$ to $0.5 \mathrm{ha})$. Today the fields can be irrigated, but in preand early Spanish time the lack of rain was the main problem for agriculture 2 Wheat, alfalfa, and chili pepper have joined the traditional crops of corn, beans, and squash. All the land is the property of the whole pueblo community, and no one may buy or sell any. A single family is allowed to use certain fields and to leave them to its children, so today the whole cultivated area is in private use. Formerly the right of use could be annulled by the elected chiefs of the community if the owner did not behave as expected, but no longer; the right of use has passed slowly over into a right of possession.

The village form and field pattern of today, and the economic and social organization, are the product of the dynamics of the pueblo society and the impact of the Spaniards and later

${ }^{1} \mathrm{~A}$ few ranchitos close to the pueblo are still inhabited, sometimes year-round as single family houses.

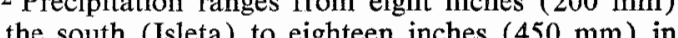
in 
of the Anglo-Americans. For eight centuries the pueblo culture had no significant contact with another culture. The arrival of the Spaniards in the sixteenth century introduced a new period. Churches and missions were built in many pueblos, and the administration of the villages was organized. Many new settlements arose. The Indians were forced to make contributions and services. Incorporation into the United States also had a major impact, because of technical and commercial development. New traffic arose, new urban and agricultural settlements were built, and manufacturing developed. Numerous people from the East moved into the area and had considerable influence on the culture of the Pueblo Indians This paper is concerned with the appearance of the villages and field patterns before the arrival of the Europeans, and the forces by which they were formed.

\section{THE PUEBLOS}

Today there are twenty-five pueblos in New Mexico and Arizona. In the sixteenth century when the Spaniards arrived, there were many more in the southern and southeastern outskirts of the Jemez Mountains, in the Rio Grande valley between Taos and Socorro, and east of the Manzano and Sandia mountains where today one finds only forests and grassland. ${ }^{3}$ Many of these villages were only partly occupied.

${ }^{3}$ The number of pre-Spanish pueblos was estimate at sixty to seventy by Alfred V. Kidder, An Introducat sixty to seventy by Alfred V. Kidder, An Introduc-
tion to the Study of Southwestern Archaeology, With
an Introduction on Southwestern Archaeology Today an Introduction on Southwestern Archaeology Toda Yale University Press, 1962), p. 343, but in 162 Spanish missionary Benavides claimed that he had baptized Indians in ninety pueblos; Frederik W. Hodge, G. P. Hammond, and Agapito Rey, eds Revised Memorial of Alonzo de Benavides, 1634, Coronado Historical Series, Vol. 4 (Albuquerque: New Mexico Historical Society, 1945). Recent archaeological evidence suggests an even larger number. For example, the recent pueblo Jemez had at least nineteen precursors; Florence Hawley Ellis, A ReconstrucWith Comparis Jemez Pattern of Social Organization cations in Anthropology, No 11 (Albuquerque: University of New Mexico Department of Anthrop 1964); and the Rio Grande area has at least ninety ruins; H. P. Mera, Population Changes in the Rio ruins; H. P. Mera, Population Changes in the Rio No. 9 (Santa Fe: Laboratory of Anthropology, New Mexico Archaeological Survey, 1940). Still more pueblos were north of Santa $\mathrm{Fe}$ and in northern Arizona.
The villages differed in detail. Those of the Jemez people were built mainly of rocks smeared with clay. A square plaza of about 0.1 to 0.2 acres $\left(400\right.$ to $800 \mathrm{~m}^{2}$ ) was surrounded by one to four storied houses which were connected with each other. Sometimes one or more apartment wings surrounded other plazas. ${ }^{4}$ Each pueblo had several mostly circular kivas, the cult rooms of different religious societies. The pueblos of the Galisteo region, south of Santa Fe, consisted of a large number of buildings, some connected, some separate. ${ }^{5}$ The pueblos of the Bandelier region, in the eastern Jemez Mountains, differed from both. It should be possible to work out the different culture areas in the pueblo region by mapping the types of settlement which belong together by origin and development.

Excavations show that most of the pueblos consisted of a hundred or so rooms of 50 to 170 square feet $\left(4\right.$ to $\left.15 \mathrm{~m}^{2}\right){ }^{6}$ Groups of rooms were connected by door openings, so an apartment-like structure can be supposed. It is difficult to estimate the number of inhabitants of a pueblo from the size of its ruins. For instance, it is not certain that all rooms of the pueblo were used at the same time. Parts of some pueblos fell into disrepair while new parts were being built. Not all rooms were used as living rooms; at Unshagi about half of the rooms were furnished only poorly and probably. were used as storerooms. Only the third which had fireplaces and the twenty percent which were well furnished could have been used as living rooms or for religious purposes. ${ }^{7}$ The

${ }^{4}$ E. L. Hewett, Antiquities of the Jemez Plateau, New Mexico, Bulletin 32 (Washington: Bureau of American Ethnology, 1906)

5 Nels C. Nelson, Pueblo Ruins of the Galisteo Basin, New Mexico, Anthropological Papers, Vol. 15, Part 1 (New York: American Museum of Natural History, 1914)

Alfred Kidder, Pecos, New Mexico: Archaeological Notes, Papers, Vol. 5 (Andover, Massachusetts: Phillips Academy, Robert S. Peabody Foundation for Archaeology, 1958); Paul Reiter, The Jemez Pueblo Ex Unshagi, New Mexico, With Notes on the Earlier Excavations at "Amoxiumqua" and Giusewa, Bulletin (Albuq, Monograph Seres, Vol. 1, Nos. 4 and 5 and Mariorie F. Inambert Paako: An Archaol 1938); and Historical Chronicle of an Anasazi Indian Village in North Central New Mexico, Monograph No. 19 (Santa Fe: School of American Research, 1954). parts I-V.

Reiter, op. cit., footnote 6, p. 63. family and household structure must be considered. Kidder assumed that a family of five people lived in six coherent rooms, and concluded that Pecos (with 1,020 rooms) was inhabited by about 850 Indians. ${ }^{8}$ This estimate seems low, because even today two to three somewhat larger rooms are sufficient for a family of four or five persons.

$$
\text { THE STUDY AREA }
$$

A small area was investigated to obtain exact information about the economic area of a preSpanish pueblo. The choice of the area depended on two conditions:

1) the area should have been deserted immediately after the arrival of the Spaniards, so that no important European influence could have taken place; and

2) the traces of only one settlement period might be represented, because each period had its own specific economic patterns, and it would be difficult to date the relics if the area had been used ove several periods.

Both conditions were realized in an almost ideal way in the northern Jemez valley, which was cleared by the Jemez Indians at the end of the P III period, reoccupied during the P IV period, and deserted a short time after the arrival of the Spaniards in the seventeenth century (Fig. 1). ${ }^{9}$

The area is on the southwestern slope of the Jemez Mountains, a Pleistocene volcano about $60 \mathrm{~km}$ in diameter. The center is a caldera, in which the Redondo Peak rises to an elevation of 11,254 feet $(3,400 \mathrm{~m})$. Pumice and rhyolitic lava build up the subsoil. The elevation of the study area drops from 8,600 to 7,300 feet $(2,600$ to $2,200 \mathrm{~m})$. The headwaters of the Jemez River, San Antonio Creek, and East Fork have cut deep notches. San Diego Canyon is more than 1,750 feet $(500 \mathrm{~m})$ deep. Red Permian sandstones are exposed beneath the volcanic rocks. In the northern part of the canyon the San Antonio-Jemez River and the East Fork have carved the Battleshiprock, lava rock which is revered as a shrine by the Jemez Indians.

8 Kidder, op. cit., footnote 6, p. 122.

9 The P(ueblo) III period lasted from about 1050 until about 1300, and the P(ueblo) IV period from about 1300 until about 1700 .
These rivers and some smaller creeks served the Indians with drinking water. The other valleys and plateaus are dry except during episodic rainfalls and a short time after the melting of the snow. Numerous little dry valleys, called arroyos, score the slopes of the canyons and the plateaus. The slopes of the valleys are stepped by numerous small terraces which were important for the agriculture of the former pueblos. The area has fourteen to eighteen inches ( 350 to $450 \mathrm{~mm}$ ) of precipitation per year, mainly heavy rainshowers; a great part runs off superficially. Pinyons, oak, and juniper bushes are the main plants.

The Nanishagi and Unshagi pueblos are between arroyos on small terraces about 100 to 160 feet $(30$ to $50 \mathrm{~m}$ ) above the Jemez River. The third-not definitely determinable-village ruin occupies a slope terrace about 600 feet $(180 \mathrm{~m})$ above the East Fork, near a hot spring (Fig. 2). In contrast to Unshagi, the ruins of Nanishagi and the Hot Spring Pueblo, as I have named it, have been examined only slightly by archaeologists. ${ }^{10}$

\section{THE ECONOMY}

\section{Fieldhouses and Small Caves}

The pueblos are not the only buildings in this area. The ruins of 277 small buildings are scattered over the slopes, terraces, and valley bottoms. ${ }^{11}$ Usually a bit of the walls with one to three layers of stones is still visible. The walls consisted of rough natural rocks smeared over with clay. A door opening led outside.

10 Nanishagi is discussed in Paul Reiter, William T. Mulloy, and E. H. Blumenthal, Preliminary Report of New Mexico Bulletin, Anthropological Series 3, No. 3 (Albuquerque:- University of New Mexico, 1940). Ceramic material indicates that the Hot Spring Pueblo was also occupied during the P IV period.

${ }^{11}$ Hewett, op. cit., footnote 4, p. 51, mentioned such structures, and they have been reported from other parts of the Southwest. Those in southern Arizona and the San Juan River drainage area date mostly from the P III period; Richard B. Woodbury, Prehistoric Agriculture at Point of Pines, Arizona, can Archaology, 1961); and William J Adams and Nettie K. Adams An Inventory of Prehistoric Sites in the Lower San Juan River, Utah, Bulletin No. 31 (Flagstaff: Museum of the University of Northern Arizona, 1959). Similar ruins are shown on a 1:24,000 topographic quadrangle of the Bandelier National Monument in the eastern part of the Jemez Mountains. 


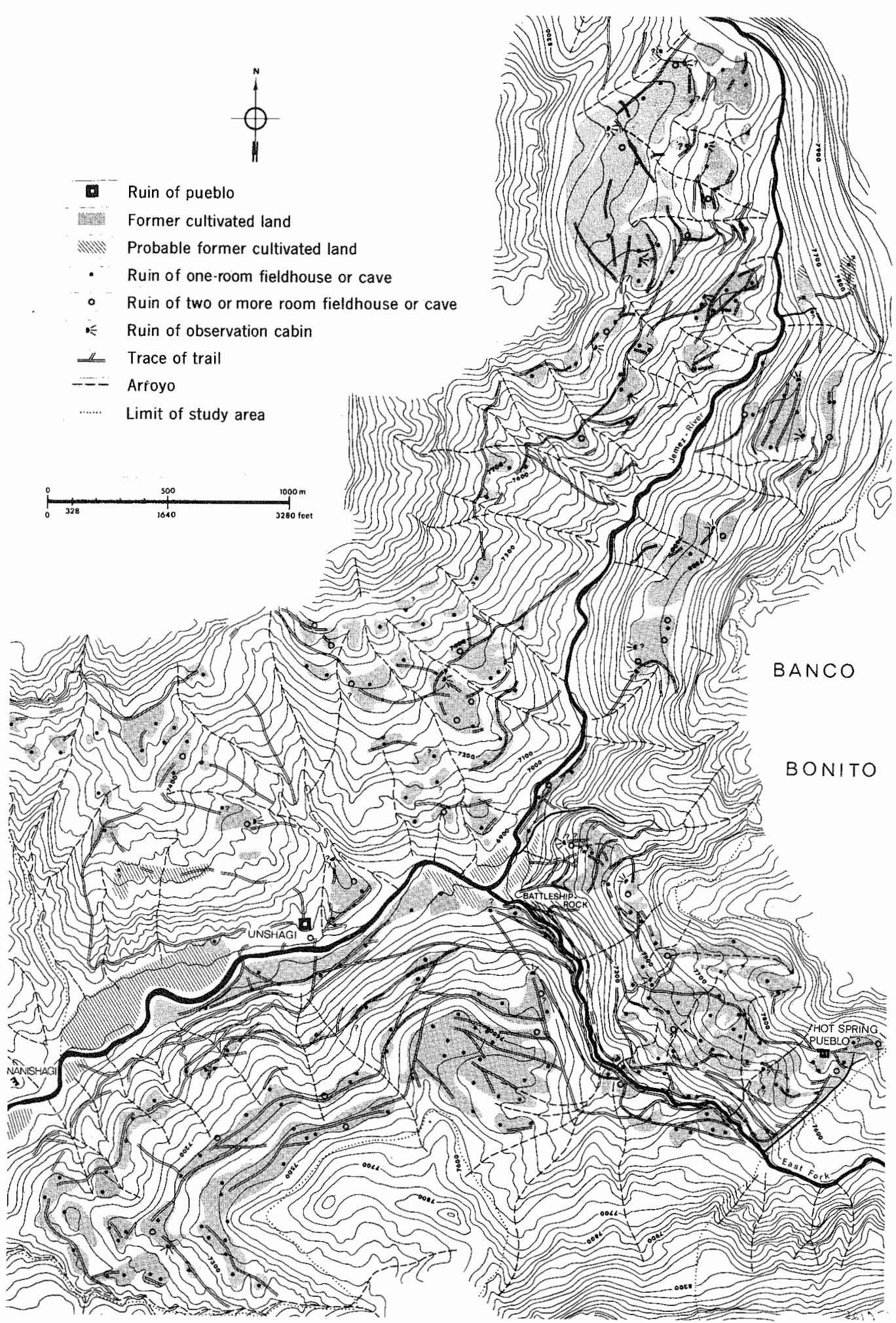

FIG, 1. General map of pre-Spanish relics in upper Jemez Canyon.

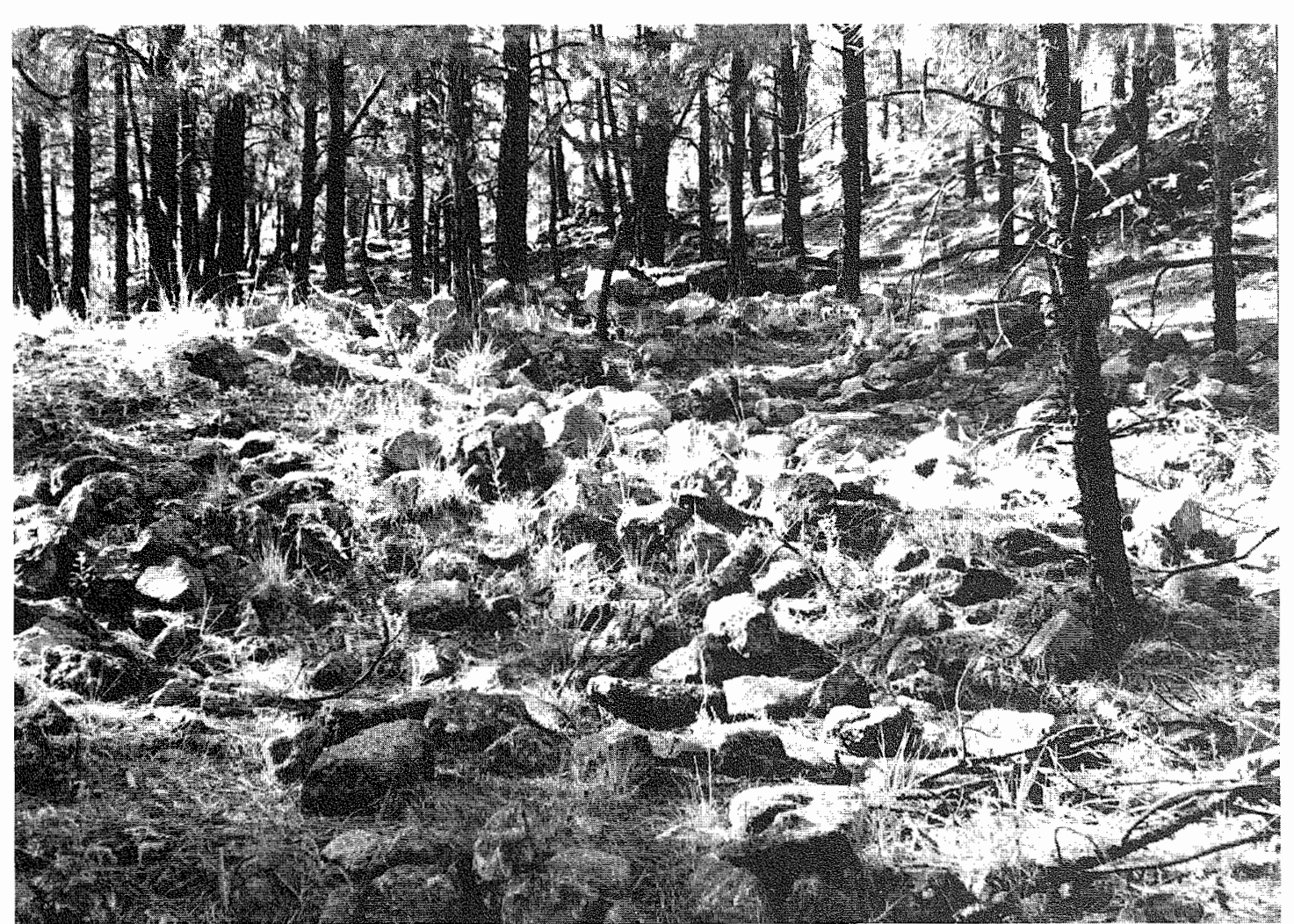

FIG. 2. Ruins of the Hot Spring pueblo.

Some better conserved structures show that the roof was made of woodwork and probably completed by twigs and clay. Potsherds were found near most of the houses. Their typological classification (Jemez Black on White and Culinary, sometimes Glaze) attests that the buildings were occupied at the same time as the pueblos, in the P IV period. It is possible to identify four different types (Fig. 3):

1) houses detached or on boulders, or one room, with a base of five by seven to ten by fourteen square feet $(1.5 \times 2.0$ to $\left.3.0 \times 4.0 \mathrm{~m}^{2}\right)$ comprised eighty percent of the houses (Fig. 4):12

2) houses of several (mostly two) room with a base of seven by fourteen to fourteen by sixteen square feet $(2.0 \times 4$. to $4.0 \times 5.0 \mathrm{~m}^{2}$ ), and small groups of one room houses (mostly pairs) comprised thirteen percent; ${ }^{13}$

${ }^{12}$ Including nine percent uncertain cases with very low ruins or only concentrations of sherds.

${ }^{13}$ Including ten percent uncertain cases with walls between rooms not clearly evident.
3) often overhanging rocks were substituted for a wall and a part of the roof. The concluding wall is most times constructed in a bow. Five percent of the houses were built in this manner (Fig. 5) $;^{14}$ and

4) sometimes natural cavities (small caves) could be used, probably artificially enlarged. They were two percent of the buildings; two had the size of the bigger
houses of two or three rooms (Fig. 6).15

All houses and small caves were at the edges of level areas (terraces, gentle slopes, and valley bottoms) which were formerly cultivated. Most were on elevated spots from which the fields could be watched. Hardly a field in the study area does not have such a house or small cave. I have described these structures as fieldhouses; they did not exist away from the fields. The distance between these houses was related to the openness of the area; it was smaller where the

14 Including two percent uncertain cases where potsherds were missing.

${ }_{15}$ Including one percent uncertain cases which have been partly destroyed. 


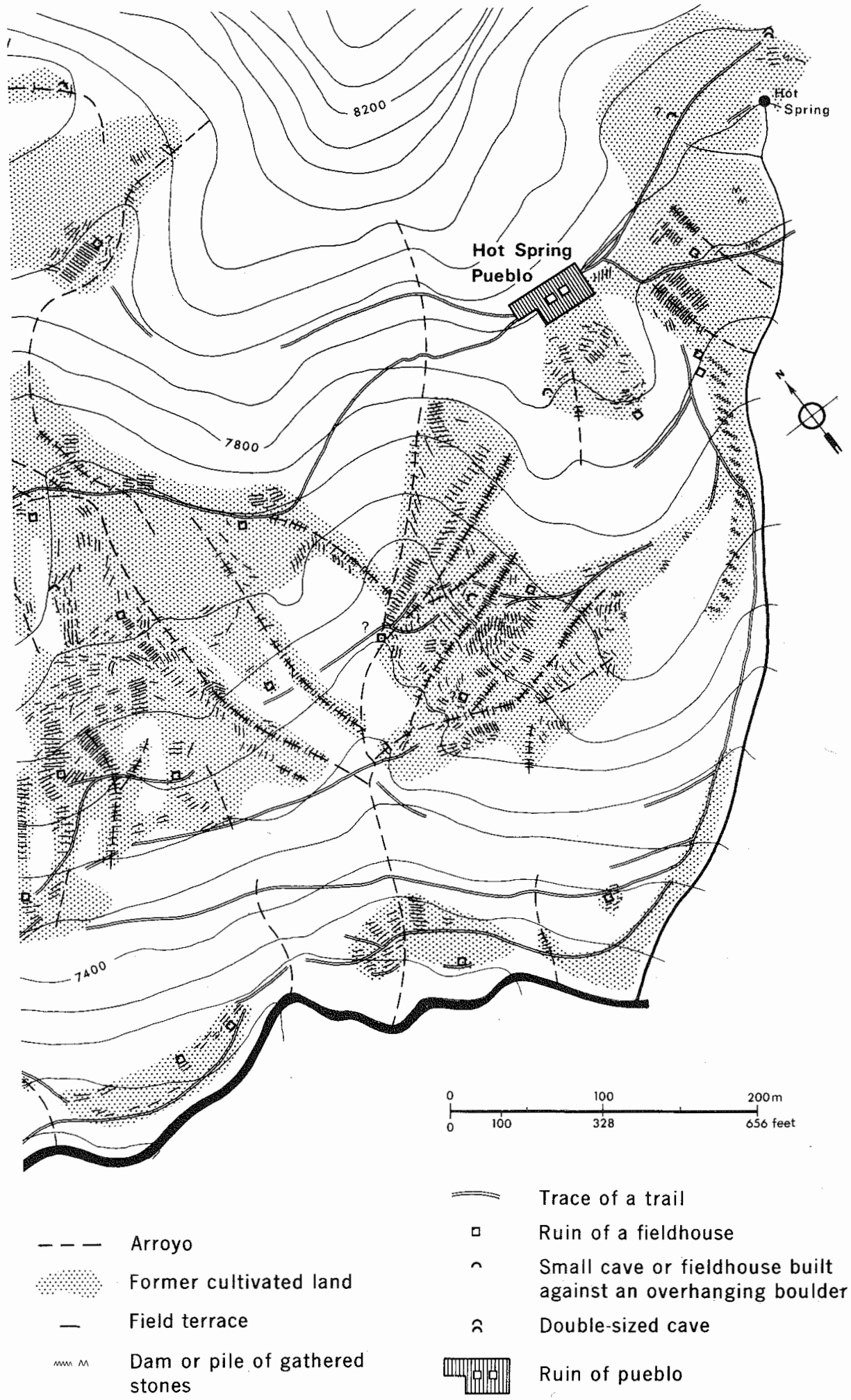

FrG. 3. Detailed map of pre-Spanish relics near the Hot Spring pueblo.

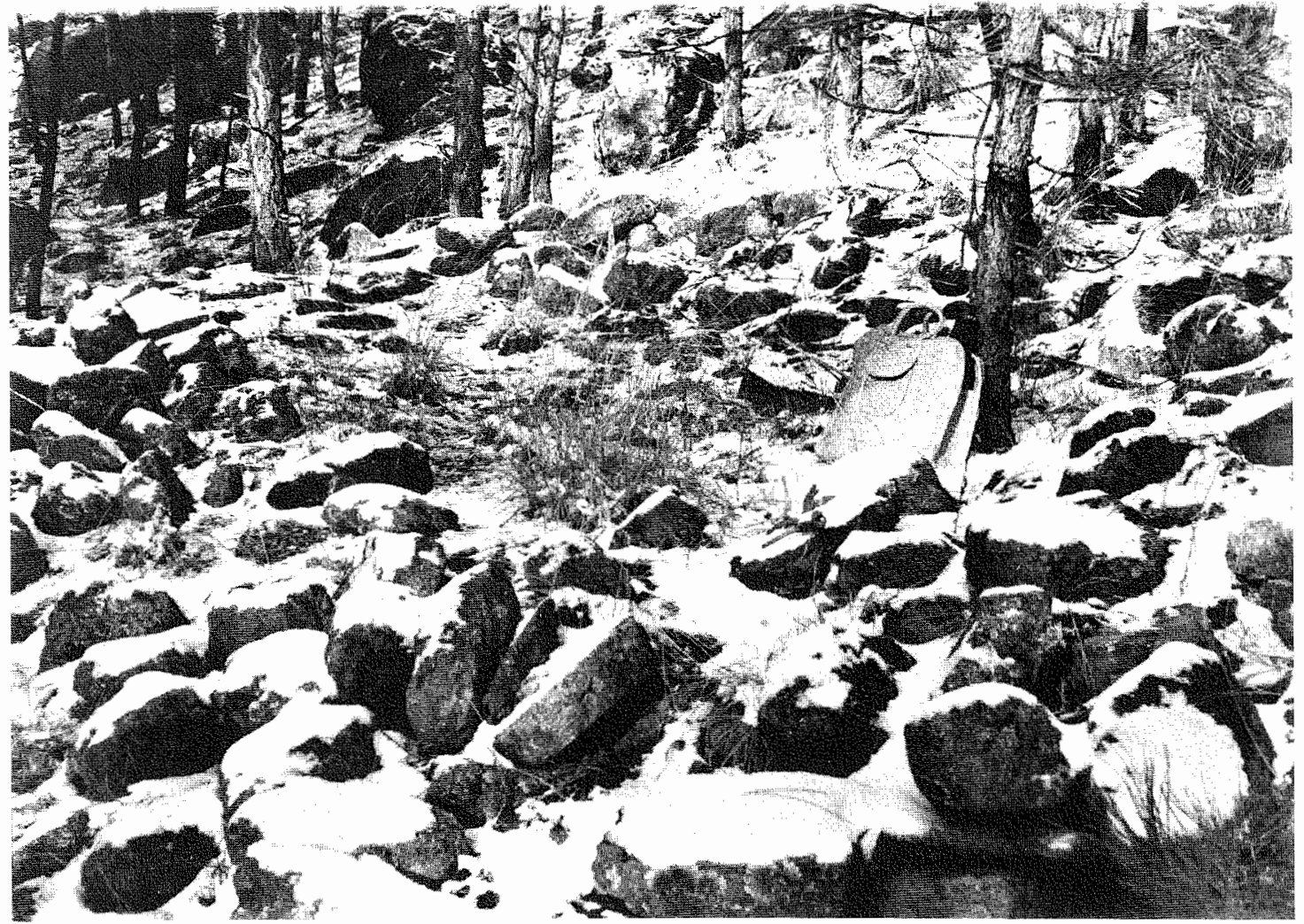

FIG. 4. Ruins of a detached one-room fieldhouse under light snow cover.

surface was undulating, and it was larger in level areas, such as at the bottom of the Jemez valley downstream from Battleshiprock (Fig. 1).

These houses contained fireplaces, stonechests (for storage?), and some had metates (grinding stones) ${ }^{16}$ The ceramic material originates from vessels which were used for storage, for getting water, and for cooking. These houses were more than temporary shelters; clearly people lived in them. Their location near the fields suggests that their occupants had a guard function. Probably the houses were occupied when the growing crops needed to be watched and protected. They might be considered precursor of the field ranchitos of recent pueblos. The small rooms in the fieldhouses indicate that only a few persons lived in them. On the other hand, if life during warm seasons took place mainly outside the houses, the fieldhouses might

16 Indicated by some excavations, for instance, by Reiter, op. cit., footnote 6. have been inhabited by single families of three to five persons.

The function of the fieldhouses might be explained in this way, but how might one explain multiroom houses and pairs of one-room houses? All rooms of these houses probably were used as living rooms. Both rooms in a two-room house near Unshagi had the same furnishing: fireplace and small stonewalls, probably walls of a former store box. ${ }^{17}$ Each room had a separate door, and I suspect that each room housed a single family. One family had the task of watching the fields, and the other was engaged in other tasks. These structures were often close to observation cabins.

\section{Observation Cabins}

The fieldhouses and caves can be distinguished from smaller cabins with a base of three by three to five by five square feet $(0.8 \times$ 0.8 to $1.5 \times 1.5 \mathrm{~m}^{2}$ ). These could hardly have

17 Proved in one case by Reiter, op cit., footnote 6 . 


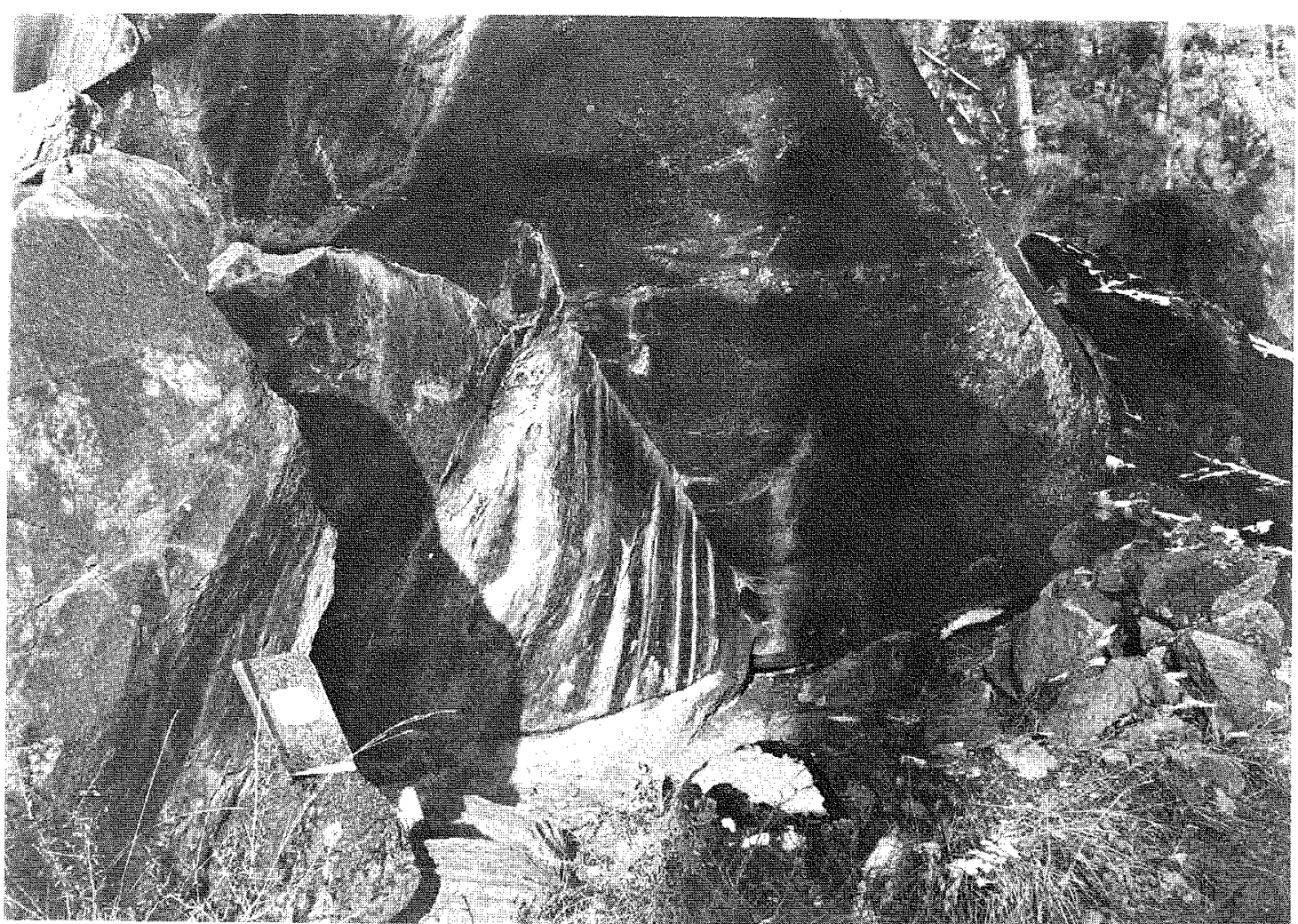

Fig. 5. Ruins of a one-room fieldhouse built against an overhanging rock. The pictograph in the upper left part of the photograph (probably the moon, the sun, or a star) is unusual in the study area.

served as lodging places for a whole family (Fig. 7). I found almost no pottery which would indicate cooking and eating. Elevated spots with a command of the valley were the preferred location. The distances between these buildings averaged 1,400 feet $(400 \mathrm{~m})$, much larger than the 250 feet $(84 \mathrm{~m})$ between the fieldhouses and small caves. I believe that these structures were observation cabins built for a single person. His task would have been to watch a larger area of the valley. These watchers might have communicated with each other by light or smoke signs. Most of the observation cabins were less than 500 feet $(150 \mathrm{~m})$ from multiroom houses and pairs of one-room houses. Perhaps the inhabitants of one room of such houses also had to man the cabins.

The observation cabins, fieldhouses, and small caves indicate that the Indians feared hostilities as well as damage by animals. The whole agricultural area could be controlled and defended against little groups who might have intended field robbery and devastation. The Navajos and Apaches today living north and west of the Pueblo area were warlike hunters and gatherers who often devastated the Indian fields. They arrived in the Rio Grande drainage in the fifteenth century. The construction of the fieldhouses, and probably also the observation cabins, however, can be traced back by pottery to the first appearance of the pueblos in this area in the thirteenth or fourteenth century. Perhaps Navajos and Apaches had similar warlike precursors; it is very difficult to come to a conclusion because of rarity of datable traces. Certainly gatherers and hunters caused hostilities in the thirteenth century in northwest New Mexico. ${ }^{18}$

18 Edward T. Hall, Jr., Early Stockaded Settlements in the Governador, New Mexico, Columbia Studies in Archaeovernador, New Mexico, Columbia Studies in York: Columbia University, Vol. 2, part 1 (New ology, 1944); and Edward T. Hall, Jr., "Recent Clues to Athapascan Prehistory in the Southwest," American Anthropologist, Vol. 46 (1944), pp. 98-105.

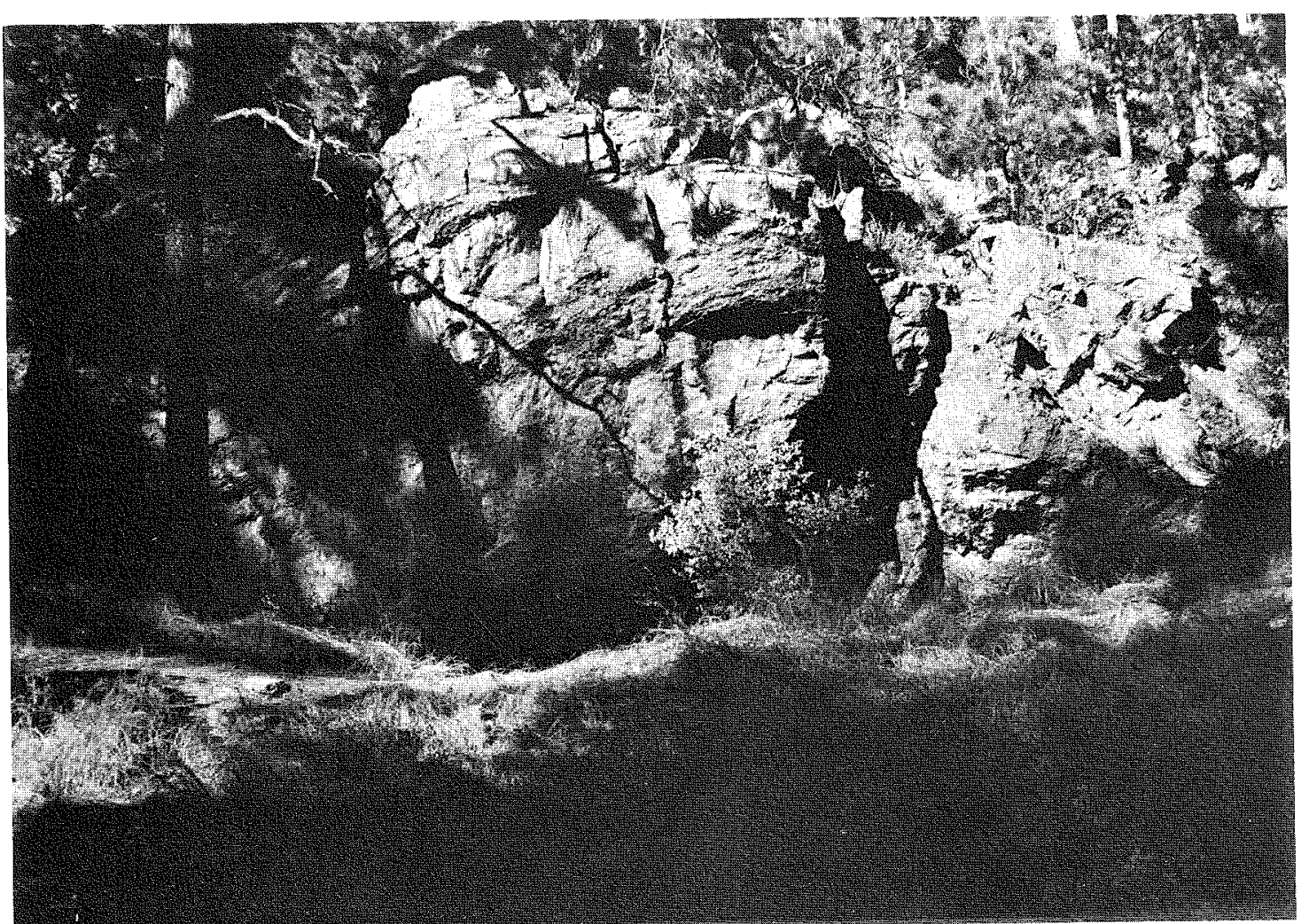

Fig. 6. Entrance to a small cave.

The Fields

The system of fieldhouses, small caves, multiroom houses, and observation cabins assumes tight organization of the pueblo society. The field pattern supports this conclusion. The flatter areas were used as fields. Former fields can be recognized by the relief, by the condition of the soil, and by the relics of agricultural use. The valley slopes are interrupted by several terraces. Slopes of $15^{\circ}$ to $40^{\circ}$, mainly near the Hot Spring Pueblo, have been made arable by artificial terraces. The flatter areas have deepe soils and heavier vegetation. The traces of agricultural cultivation are the most importan indicators of former fields (Fig. 3).

Small terraces are widespread; the riser was made of stones placed side by side parallel to the contour, and the flatter parts consist of soil (Fig. 8). The terraces are usually five to thirtyfive feet $(1.5$ to $10.5 \mathrm{~m})$, rarely seventy feet $(21 \mathrm{~m})$, long, and one to two feet $(0.3$ to 0.6 m) high. Usually the riser consists of a single layer of rocks, but some terraces have two to five layers. Single terraces are rare. Normally they are parts of staircase-like systems. The width of the steps varied with the slope, ranging from two to fifteen feet $(0.6$ to $4.5 \mathrm{~m})$. The level parts of some terraces had small stone rows leading from the front of the terrace to the base of the next higher one. The smooth slopes, the ridge lines of the small watersheds between the arroyos, and also the deepest parts and the heads of the arroyos were stepped by such terraces.

Similar forms have been described in different areas of the Southwest. ${ }^{19}$ They were built during

19 In northwestern New Mexico, R. Gwinn Vivian, "An Inquiry into the Prehistoric Social Organization in Chaco Canyon, New Mexico," in W. A. Longacre, .,. Reconstucting Pr historic Pheblo Socientes (Al buquerque: School of American Research, 1970), pp. fore Ceaver Creek Agriltural Communities on the San Beaver Creek Agricultural Communities on the San (1961), pp. 174-87; and in southwestern Colorado, Arthur Rohn, "Prehistoric Soil and Water Conservation on Chapin Mesa, Southwestern Colorado," American Antiquity, Vol. 28 (1963), pp. 441-55. 

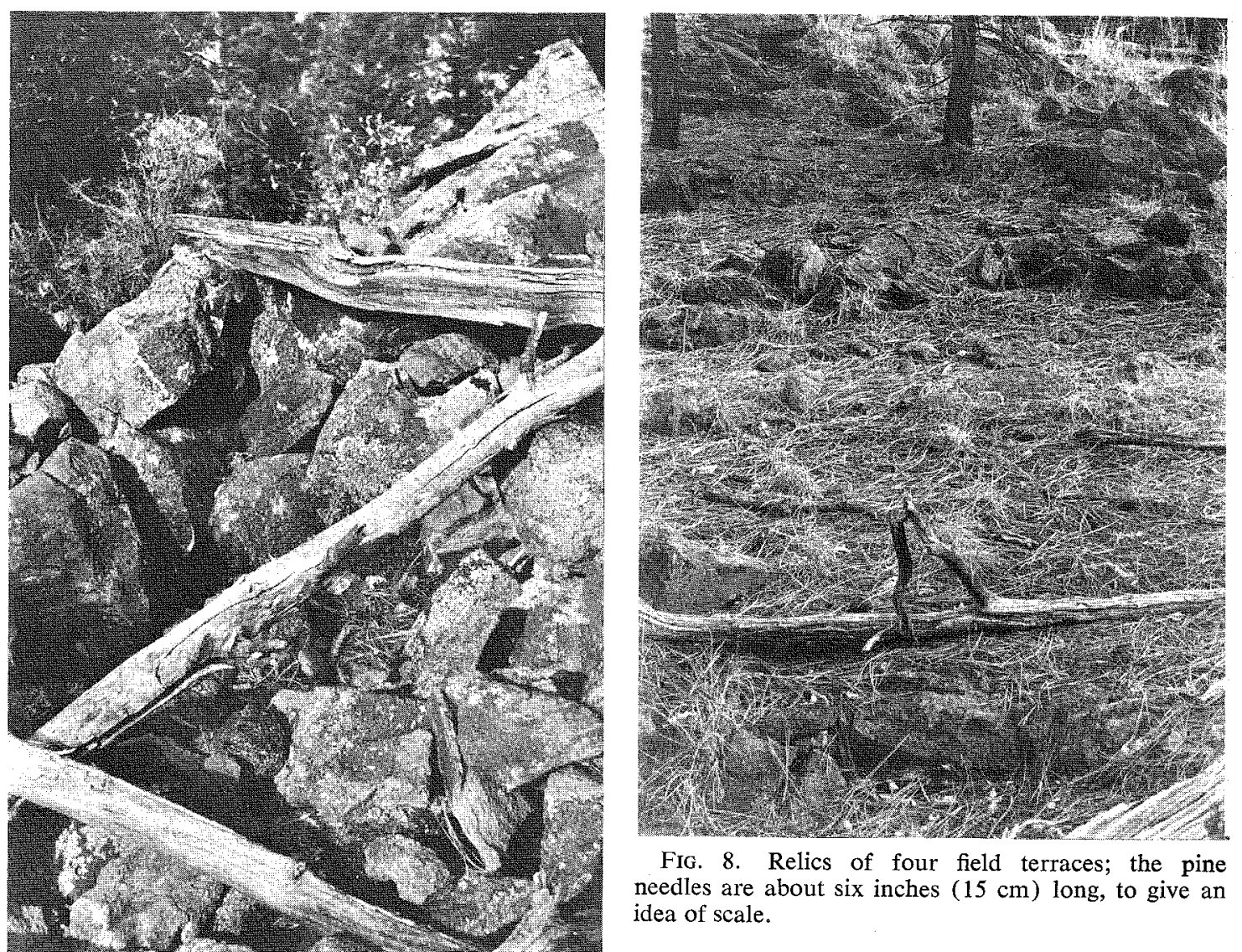

FIg. 8. Relics of four field terraces; the pine FIG. 8. Relics of four field terraces; the pine
needles are about six inches $(15 \mathrm{~cm})$ long, to give an idea of scale.

Fig. 7. Observation cabin excavated out of a hillside. The boulders measure about one foot $(0.3 \mathrm{~m})$ on ceiling.

the P III period before 1300 . Larger relics of this type (called trincheras) were built in southern Arizona and northern Mexico, probasouthern Arizona and northern Mexico, probaIt is argued that the terraces improved physical conditions for cultivation by increasing soil moisture, by reducing erosion, and by equalizing drainage. These same arguments might also have been important in the Jemez area, but alone they could not have been decisive. If

${ }^{20}$ Woodbury, op. cit., footnote 11; William A. Howard and Thomas M. Griffiths, Trinchera Distribution in the Sierra Madre Occidental, Mexico, Publications in Geography, Technical Papers, No. 66-1 (Denver: University of Denver Department of Geography, 1966); and Laurance C. Herold, Trincheras and Physical Environment along the Rio Gavilan, Chihuahua, Mexico, Publications in Geography,
Technical Papers, No. 65-1 (Denver: University of Denver, Department of Geography, 1970) reducing soil erosion and increasing moisture terraces, the such as in medieval Europe or in parts of the United States, in areas where there were no merely resulted from a rearrangement of the rocks, which covered the surface, to facilitate cultivation. On steeper slopes and in arroyo beds the terraces made arable land which othercultivation, stone rows in flat areas where the rocks are arranged in a line (Fig. 9), or small dams and heaps of gathered stones, are much less important. Stone terraces, stone rows, and associated with fieldhouses. ${ }^{21}$ The flatter parts of my study area are underlain with pumice

${ }^{21}$ Similar observations have been made in Arizona by Woodbury, op. cit., footnote 11, p. 14; and in southwestern Colorado by Rohn, op. cit., footnote 19 p. 443 . rocks, but they did not. Perhaps the terraces wise would have been useless. Other prints of the other traces of agricultural use are often

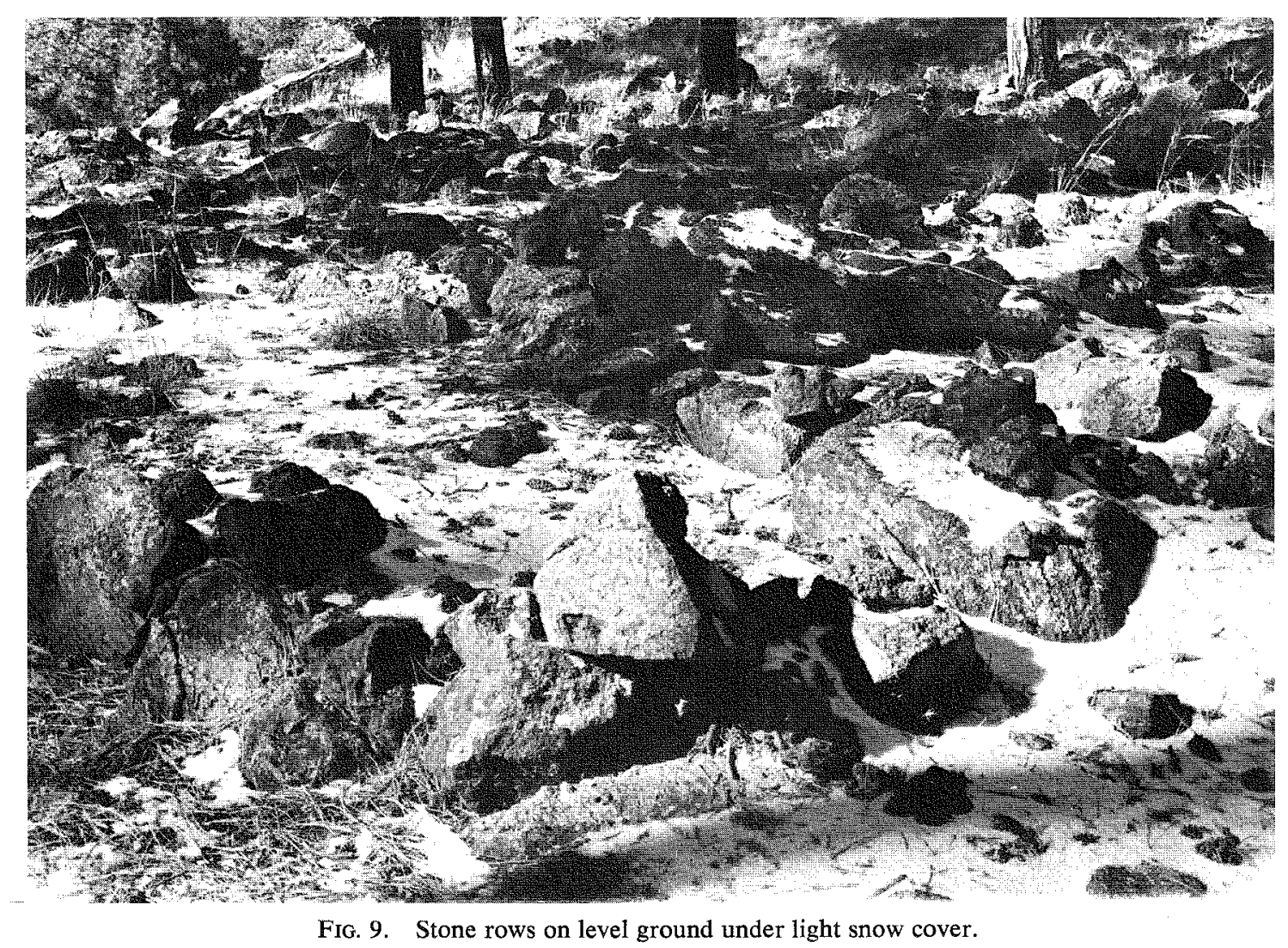

tephra. Stony hills of lava rise above these level areas. The tops of many of these small lava hills have fieldhouses, built of the stones which cover the hill, and the sides of the hill are stepped with terraces.

The size of the agricultural area of the Pueblo Indians can be outlined with an accuracy of eighty to ninety percent, but it is not easy to define the field patterns from these relics. Field studies in Europe have shown that the relics of agricultural use can be interpreted not only with regard to the natural environment but also to the economy and tenure. ${ }^{22}$ In Europe several relics, such as terraces and ditches, can be regarded as limits of fields and beds, the smallest units in agricultural economy, but Europe is an old ploughing area. The field pattern in the old Indian area must be seen in another way. The stone terraces and rows have a narrowness which is possible only in areas

${ }^{22}$ Hans Mortensen and Kurt Scharlau, "Der siedlungskundliche Wert der Kartierung von Wüstungsfluren," Nachrichten der Akademie der Wissenschaften in Göttingen (1949), pp. 303-31. where the digging stock and perhaps the hoe were the main tools. Most of the terrace edges and stone rows are not connected, so they did not enclose real fields. Moreover these relics can be found only in an area where boulders had to be arranged. The much larger stoneless regions, and mesas and valley bottoms in other parts of New Mexico, are almos free from relics of this kind. No indications of real field borders, caused by possession or economy in the former Pueblo area, are recognizable ${ }^{23}$ A comparison of these old fields with the fields of modern Pueblo Indians shows the difference very clearly. The borders between the modern fields are often marked by stone rows, if the soil contains any rocks. These fields are cultivated by their individual "possessors." Cultivation of the land in the same way by separate families in the P IV period should have left some traces.

23 Possibly some of the relics in southern Arizona described in Woodbury, op. cit., footnote 11, p. 13 Woodbury did not address this question. might be recognized as real border markers, but 


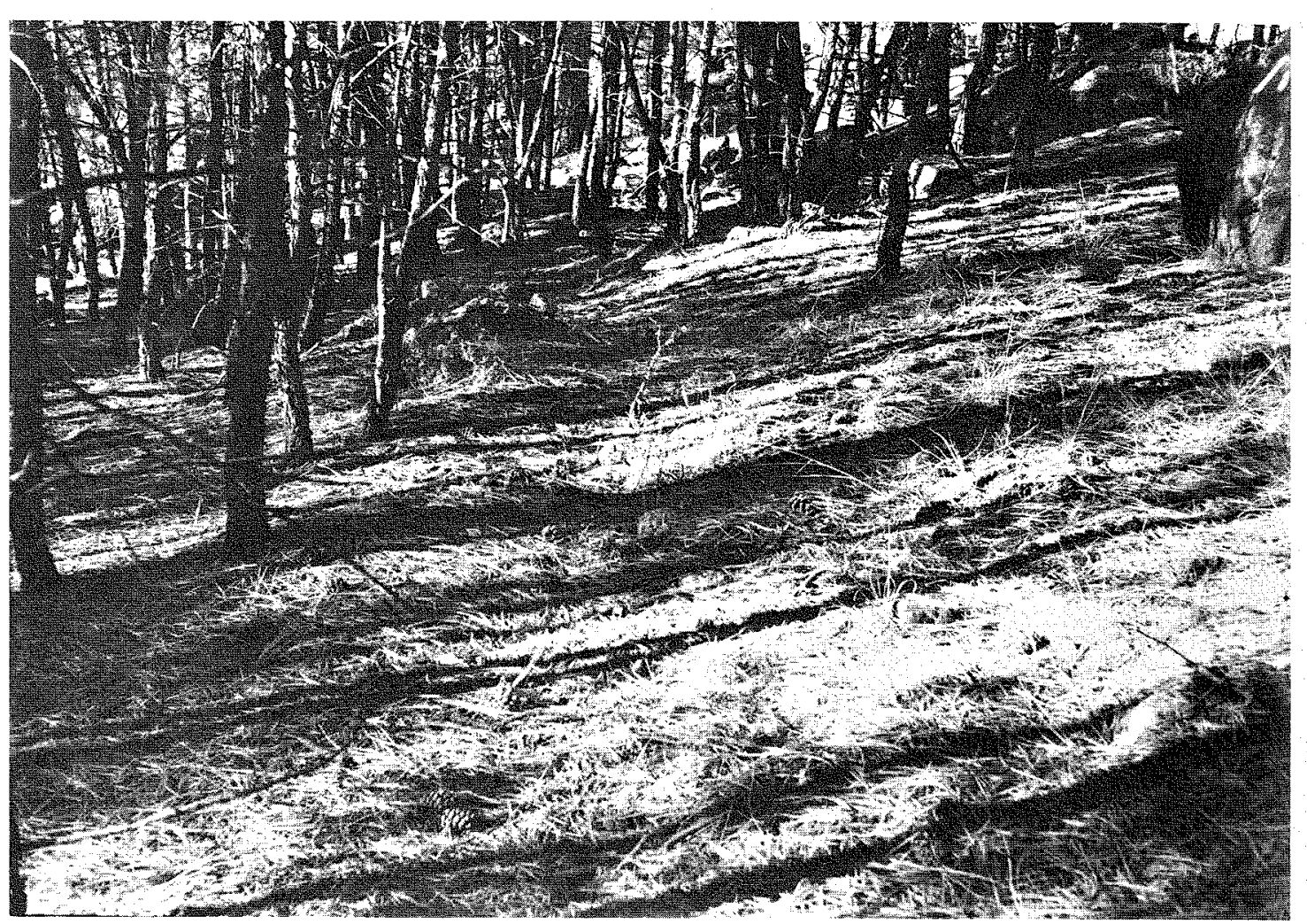

Fig. 10. Trace of a trail on relatively level ground.

If it is not possible to recognize limits of possession in the fields, there arises the question, who possessed the fieldhouses and small caves? Were they possessed by families, who lived in them in the summer? A negative answer is suggested by the fact that the density of the houses conforms to the topography. The fields which would belong to such a house in a hilly area were small, a quarter acre $(0.1 \mathrm{ha})$ or even less, but other houses had areas of ten acre (4 ha) or more. Houses on plains in other parts of northern New Mexico had field areas of up to 250 acres $(100$ ha $) .{ }^{24}$ These great differences do not support the supposition that the houses were on private land; the "farms" would have had to have had extraordinarily different sizes. The population in the attached pueblos would also have had to have varied considerably, which is not probable, because the village ruins

24 Dietrich Fliedner, "Über die Entstehung der Siedlingsformen und Siedlungsräume im Bereich der Pueblo-Indianer New Mexicos (USA)," Göttinger Geographische Abhandlungen (Ha
schrift), Heft 60 (1972), pp. 467-81. are nearly equal in size. I conclude that the fieldhouses and the surrounding fields belonged to the village community and were cultivated in common. The farm land of modern pueblos still is owned by the whole tribe, probably consequence of pre-Spanish ownership conditions.

System of Trails

Any discussion of the size of the agricultural area belonging to the different pueblos is hindered by a lack of traces of real field borders and of any relics which seem to have marked the limits between the areas of the different villages, but several relics of former foottrails have to be seen, like trafficways generally, as visible manifestations of economic coherence.

The relics of trails are about twenty inches $(50 \mathrm{~cm})$ wide and eight inches $(20 \mathrm{~cm})$ deep in smooth terrain (Fig. 10). Trails running parallel or oblique to the contours are dug into the slope; the builders moved material from the hillside to the valleyside to enlarge the path (Fig. 11). Sometimes stones have been place

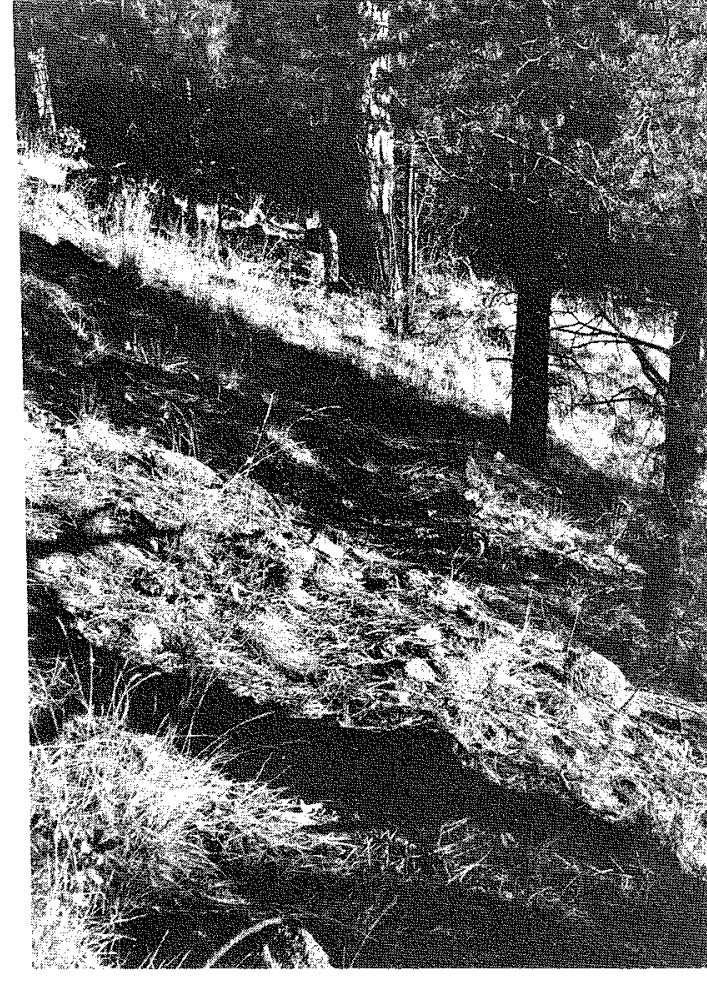

FIg. 11. Trace of a trail on sloping ground.

at the valleyside for a better foundation. In rocky slopes the horizontal or nearly horizontal trails were engraved. In some rocky ravines (fo instance, north of the Battleshiprock) small half moon shaped deepenings for hands and feet were cut into the walls.

These traces of former trails are parts of systems which have not previously been studied. ${ }^{25}$ They cannot be confused with the trails of game if they have artificial foundation or similar artifacts. Where such artifacts are missing the arrangement of the economic area is the most important indication, because the trails connected the different objects in the cultivated area. Four route types are characteristic (Figs. 1 and 3):

1) between the fieldhouses, small caves, an observation cabins, especially when they

${ }^{25}$ Single trails in different parts of the pueblo area have been identified in Bertha P. Dutton, "Highlights have been identified in Bertha P. Dutton, "Highlights
of the Jemez Region, With Notes on What to See and How to Get There," El Palacio, Vol. 59 (1952), pp. 131-58; and Richard Howard, "Comments on the Indians' Water Supply at Gran Quivira National Monument," El Palacio, Vol. 66 (1959), pp. 85-91. are at nearly the same altitude, as for example in the area south of the Jemez River and the East Fork;

2) between the fieldhouses (or small caves) and streams; especially typical is the trail sloping down to a stream against the current, as for example to the small creek north of the Battleshiprock

3) between the pueblo and the fieldhouses (or small caves) in a radial pattern; and

4) bypassing the agricultural area to connect with distant points.

One has the impression that the trail relics re parts of systems which centered in the former pueblos. The system west of the Jemez River was connected with Unshagi, and the eastern system north of the East Fork with the Hot Spring pueblo. The southern system was also oriented towards Unshagi; some fords connected it with this village. The limit between the systems of Nanishagi and Unshagi is especially clear; the trail east of the arroyo between the two pueblos bent eastwards to Unshagi. This arroyo was the boundary between the trail systems, and probably also between the economic areas, of the two pueblos. I believe that the economic area of the Unshagi pueblo was almost totally covered by my investigation, because the valley is limited by steep rocks in the northwest and south. ${ }^{26}$

\section{ECONOMY AND POPULATION}

The separate interpretation of the different relics may leave some doubts, but they reinforce each other, and each detail gets its position in the total plan of the former Indian settlements when they are all taken together. The maps may be considered a synoptic manifestation of the pre-Spanish society and economy, and they generally confirm our knowledge of it, but different details suggest hints for possible compleion and correction.

Probably at least 500 to 625 acres (200 to $250 \mathrm{ha}$ ) of cultivated land belonged to the Unshagi pueblo. In this area I counted about 200 fieldhouses and small caves with a total of 240 rooms. During the growing season a single family probably lived in one of the houses or caves, to watch the crops and to do other jobs.

26 The boundary may have been farther south only in the southwest, east of the Jemez River, where the kilometers away. 
I do not know whether the fields were used continuously; possibly some parts always lay fallow. Perhaps a fallow was not necessary if there was a real rotation, not only corn, but also beans and squash; these three plants might have been grown at the same time in the same field, as in other parts of pre-European North America.

\section{Population Density}

The pueblo Unshagi contained 250 to 300 rooms. About 50 were furnished well, about 100 fairly, and 125 poorly. ${ }^{27}$ The first two groups contained fireplaces or other furniture indicating a living function; the other rooms were probably storerooms. If we suppose that a single family lived in most of the even smaller one room houses and caves in the cultivated areas, we may also assume that a family occupied each of the 150 better furnished rooms in the pueblo. An average family in the Jemez pueblo in the eighteenth century was 3.5 persons. ${ }^{28} \mathrm{~A}$ similar family size in the sixteenth century would give a population of 500 to 550 persons, but a modern family size of four to five persons would give 650 to $700 .^{29}$ These figures exceed the customary estimates. At its time of greatest use the Unshagi pueblo (forty percent of the land was cultivated) had a population density of about 200 persons per square mile $\left(77\right.$ per $\mathrm{km}^{2}$ ) if the pueblo had 500 to 550 inhabitants, or almost 250 (96 per $\mathrm{km}^{2}$ ) if it had 650 to 700 .

\section{The Social Structure}

These population density estimates may be supported by an examination of the social structure. Dozier explained the connections of

27 Reiter, op. cit., footnote 6.

28 There were 109 families or 373 persons in the Jemez pueblo in 1759, and 132 families in 1779 Blanche M. Harper, "Notes on the Documentary History, the Language, and the Rituals of the Jemez Pueblo," unpublished master's thesis, University of New Mexico, 1929, p. 10. In 1793 the pueblo had 489 persons; Edward Ayer, The Memorial of Fray tongo de Benavides, 1630, with comments by Fred1916) p. 244 . The definion of the "family" this time is not clear.

29 In 1942 the average family size was 46 in the Jemez pueblo and 4.4 in all New Mexico pueblos; S. D. Aberle, The Pueblo Indians of New Mexico: Their Land, Economy, and Civil Organization, Memoirs, No. 70 (Washington: American Anthropological Association, 1948), p. 90. some rooms by door openings by arguing that several single families, one to a room, were connected to form an extended family, ${ }^{30}$ The codern Hopi villages of Arizona, which have been touched by European influence much less than the pueblos of New Mexico, support this idea. The households of these villages consis of extended families who all live in rooms connected with each other. ${ }^{31}$

The pueblos are particularly stamped by their secular and religious organization. The governor, who serves for one year, has to administer the pueblo. His charge was originated by the Spaniards. The priests, whose charge goes back to pre-Spanish times, have to be considered the religious chiefs of the pueblo society. Like the rest of the religious leaders, they are not hereditary, but are elected. ${ }^{32}$ A nobility could not arise, as in Mexico. No pueblo ruin had rooms good enough for chiefs, and excavations have found no graves fitted out especially richly. No piece of land belonged to a private person; the vertical organization of society and property in the economic realm were closely combined.

Horizontal organization in cult groups is an essential element of recent pueblo society. The kivas are meeting rooms for the peculiar religious customs. These groups originated in concern for the most important necessities in life (curing, rain and fertility, protection and hunting). This religious organization and activity supposes a close unity of the village society which could be the main reason for the compact form of the pueblos. ${ }^{33}$ The equal status of all inhabitants and cult coherence are connected in an ideal way.

Organization of Defense

Gladwin regarded the pueblo as a structure or defense ${ }^{34}$ His idea was based on the good defense position of some villages upon high

30 Edward Dozier, "Southwestern Social Units and Archaeology," American Antiquity, Vol. 31 (1965) pp. $38-47$.

Fred Eggan, Social Organization of the Wester p. 28 .

32 Ellis, op. cit., footnote 3, p. 16.

${ }_{33}$ Ellis, op. cit., footnote 3 .

${ }_{34}$ Harold S. Gladwin, A History of the Ancient Southwest (Portland, Maine: Bond Wheelwright Burns \& MacEachern, 1957), p. 217, saw the large pueblos solely in connection with warlike hunters and gatherers. mesas, but almost as many pueblos were unprotected. The buildings offered protection only against small groups of aggressors. The fieldhouses and observation cabins show that the Indians reckoned on the necessity of defense if these structures were links of a warning system. Perhaps the form of the village and its area must be explained by the necessity of defense as well as by cult and economic peculiarities.

\section{Regional Organization}

Social and economic ties and the organization of defense were very close within the village communities, but the connections between villages were loose. ${ }^{35}$ Probably only one

${ }^{35}$ Edward Dozier, The Pueblo Indians of North America, Case Studies in Cultural Anthropology (New York: Holt, Rinehart and Winston, 1970), p. 209. trail led from one to another (Fig. 1). The village peoples were economically selfsufficient, and did not depend on a ruler. In spite of their well developed architecture and careful economic arrangement, the pueblo societies could not organize themselves into larger regional units with central places and borders.

\section{ENVO}

Mapping relics of the past yields a picture just as interpretable as an excavation of a ruin, the study of documents in an archive, or tracing present religious and social structures back into the past. I believe that the distinctive contributions of different methods should lead to a closer cooperation of the several sciences which are concerned with the study of the past. 